\title{
SL-006 The Forgotten Global Minority: Psychology's Role In Disability Inclusion
}

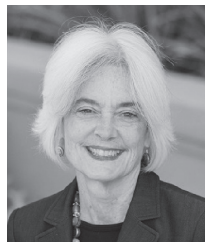

\author{
講演者 : Susanne Bruyere (Cornell University) \\ 司会者：藤川 真由（東北大学）
}

Individuals with disabilities make up approximately $15 \%$ of the world population, or more than one billion people (World Health Organization [WHO], 2011). However, individuals with disabilities are much less likely to be employed and far more likely to live in poverty. These disparities are a function of environmental, economic and attitudinal barriers that continue to pervade our societies and limit the opportunities for individuals with disabilities to have equal access to full community participation. In recognition of these disparities and the need to address them, in the U.S., Rehabilitation Psychology is a specialty area within psychology that focuses on the study and application of psychological knowledge and skills on behalf of individuals with disabilities and chronic health conditions, in order to maximize their health and welfare, independence and choice, functional abilities, and social role participation across the lifespan. The U.S. experience illustrates that psychologists can play a significant role to assist in changing the inequality equation for individuals with disabilities by advocating in the larger context for more equitable participation by people with disabilities in all facets of society. In particular, the facilitation of equitable employment participation not only will assist in economic independent for individuals with disabilities, but also their fuller participation in all facets of society. Psychologists can assist in improving employment outcomes for individuals with disabilities in their respective societies by promoting workplace disability inclusion policies and best practices to employers, and conducting the research needed to empirically document how we can apply these practices more effectively. 